\title{
Closed Fracture of the Medial Malleolus Accompanied by A Rupture of the Tibialis Anterior Tendon: An Unusual Case Report
}

\section{Medial Malleol Kapalı Kırı̆̆ına Eşslik Eden Tibialis Anterior Tendon Rüptürü: Nadir Görülen Bir Olgu Sunumu}

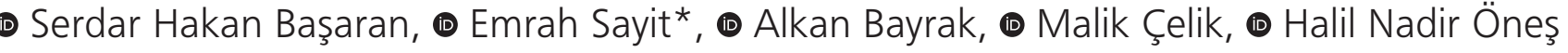 \\ istanbul Bakırköy Dr. Sadi Konuk Training and Research Hospital, Clinic of Orthopedics and Traumatology, Istanbul, Turkey \\ Samsun Training and Research Hospital, Clinic of Orthopedics and Traumatology, Samsun, Turkey
}

\section{Abstract}

Isolated medial malleolus fractures comprise two-thirds of all ankle fractures and are rarely accompanied by a posterior tibial tendon rupture and dislocation. However, a medial malleolus fracture accompanied by an anterior tibial tendon rupture is unusual, and has not yet been reported. In this paper, a case of medial malleolus fracture accompanied by a tibialis anterior tendon rupture is presented and discussed.

Keywords: Medial malleolus, fracture, anterior tibial tendon, rupture

\section{Introduction}

Ankle fractures are among the most frequently seen fractures, and age, bone quality, increased body weight, previous ankle fracture, and the mechanism of the injury are the most important risk factors $(1,2)$. The incidence is approximately 187 fractures per 100.000 people each year (3). Isolated medial malleolus fractures comprise two-thirds of all ankle fractures (4) and are rarely accompanied by tendon ruptures. Medial malleolus fractures accompanied by a posterior tibial tendon rupture and dislocation have been reported $(5,6)$, however, a medial malleolus fracture accompanied by an anterior tibial tendon rupture is unusual, and has not yet been reported. In this paper, a medial malleolus fracture accompanied by a tibialis anterior tendon rupture is presented and discussed.
İzole medial malleol kırıkları tüm ayak bileği kırıklarının üçte ikisini kapsar. Nadiren posterior tibial tendon rüptürü ve dislokasyonu eşlik eder. Bununla birlikte, anterior tibial tendon rüptürüne eşlik eden medial malleol kırı̆̆ı nadirdir ve henüz rapor edilmemiştir. Bu nedenle; bu olgu çalışmasında, tibialis anterior tendon rüptürü eşliğinde medial malleol kırı̆̆ı sunulmuş ve tartışılmıştır.

Anahtar Sözcükler: Medial malleol, kırık, Anterior tibial tendon, rüptür

\section{Case}

A 54-year-old man was admitted to the hospital with a crush injury of the ankle caused by a log. Physical examination revealed medial left ankle and medial midfoot swelling and tenderness. Limited ankle movement was thought to be due to severe pain. There was no additional injury, and neurovascular examination was normal. On the anteroposterior and lateral radiographs of the ankle, an isolated medial malleolus fracture was seen (Figure 1). After the application of a temporary short-leg splint, the patient was taken into surgery. During the operation, it was noticed that the tibialis anterior tendon had ruptured. After fixation of the medial malleolus by two $4.5 \mathrm{~mm}$ cannulated screws, the incision was extended towards the medial cuneiform. It was then detected that the tendon
Address for Correspondence/Yazışma Adresi: Serdar Hakan Başaran İstanbul Bakırköy Dr. Sadi Konuk Training and Research Hospital, Clinic of Orthopedics and Traumatology, İstanbul, Turkey

Phone: +90 2124147114 E-mail: drserdarhakan@gmail.com ORCID ID: orcid.org/0000-0002-9715-9530 Received/Geliş Tarihi: 20 October 2017 Accepted/Kabul Tarihi: 14 March 2018
Copyright 2018 by The Medical Bulletin of University of Health Sciences Haseki Training and Research Hospital
The Medical Bulletin of Haseki published by Galenos Yayınevi.

๑Telif Hakkı 2018 Sağlık Bilimleri Üniversitesi Haseki Eğitim ve Araştırma Hastanesi Haseki Tıp Bülteni, Galenos Yayınevi tarafindan basılmıștı. 
had split from its insertion site. The distal tip of the tendon was slightly shortened and refreshed because of the degeneration. Due the shortening, it was attached to the navicular bone using two $3.5 \mathrm{~mm}$ anchors (Figure 2). After fluoroscopic control, the operation was completed, and a short-leg splint in mild dorsiflexion was applied (Figure 3).

The next day, the patient was mobilized on the healthy limb using two Canadian walkers, and was discharged on the second day. The short-leg splint was removed six weeks later, and a rehabilitation program that included passive and active ankle exercises was initiated. Full weightbearing was allowed in the eighth week after surgery. At the three-month follow up, the patient had a full range of motion (Figure 4), and the American Orthopedic Foot and Ankle Society (AOFAS) score was 90 according to mild pain after a long walk. At the six, 12, and 18 month follow ups, the patient had no complaints, and the AOFAS scores were 100.

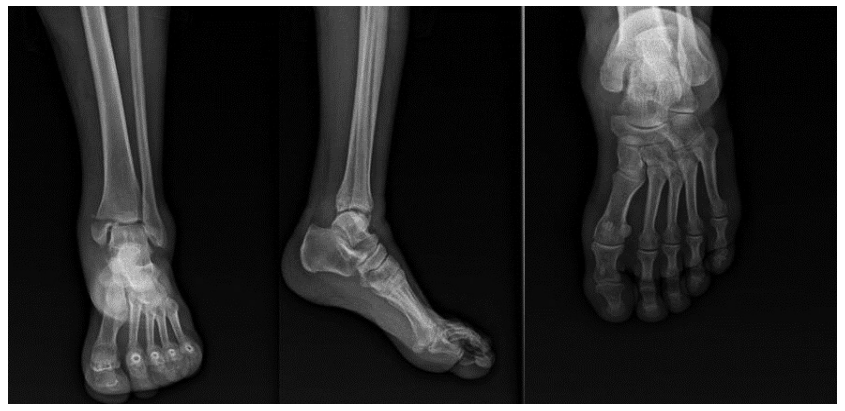

Figure 1. The anteroposterior and lateral radiographs of the ankle and the foot before surgery

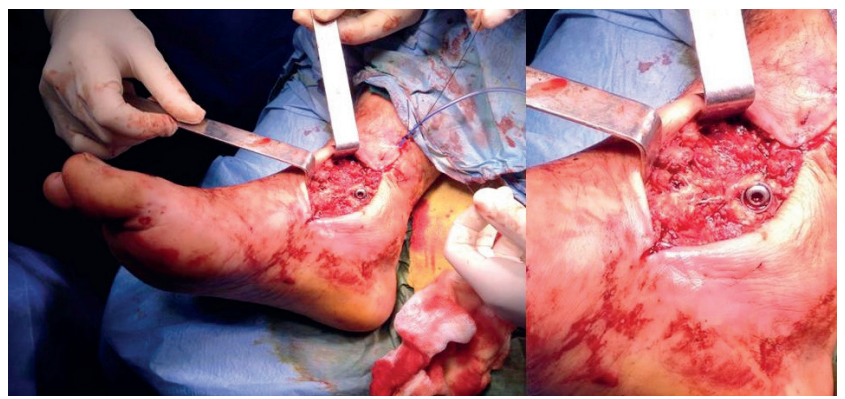

Figure 2. The fixation of the medial malleolus using two cannulated screws and the tibialis anterior tendon using two anchor sutures

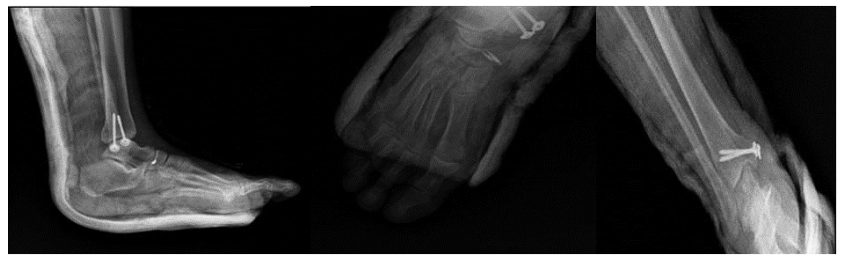

Figure 3. The anteroposterior and lateral radiographs of the ankle and the foot after surgery

\section{Discussion}

The tibialis anterior muscle is the most important muscle of the foot for dorsiflexion and is responsible for approximately $80 \%$ of the power required for this movement. It occupies the anterior compartment of the leg, and originates from the lateral condyle and upper twothirds of the lateral surface of the tibia, the interosseous membrane, and the deep surface of the fascia and the intermuscular septum. Its insertion site is on the plantar surface of the first metatarsal and the medial plantar surface of the first cuneiform. It also helps with the inversion of the foot at the subtalar and midtarsal joints, and assists with holding up the medial arch of the foot (7).

Acute rupture of the tibialis anterior tendon is quite rare and traumatic (8-11), and spontaneous ruptures due to gout, systemic lupus erythematosus, rheumatoid arthritis, diabetes mellitus, and psoriasis have been reported (12-15).

The loss of the tendon contour over the ankle and weakness of dorsiflexion of the foot are highly suggestive
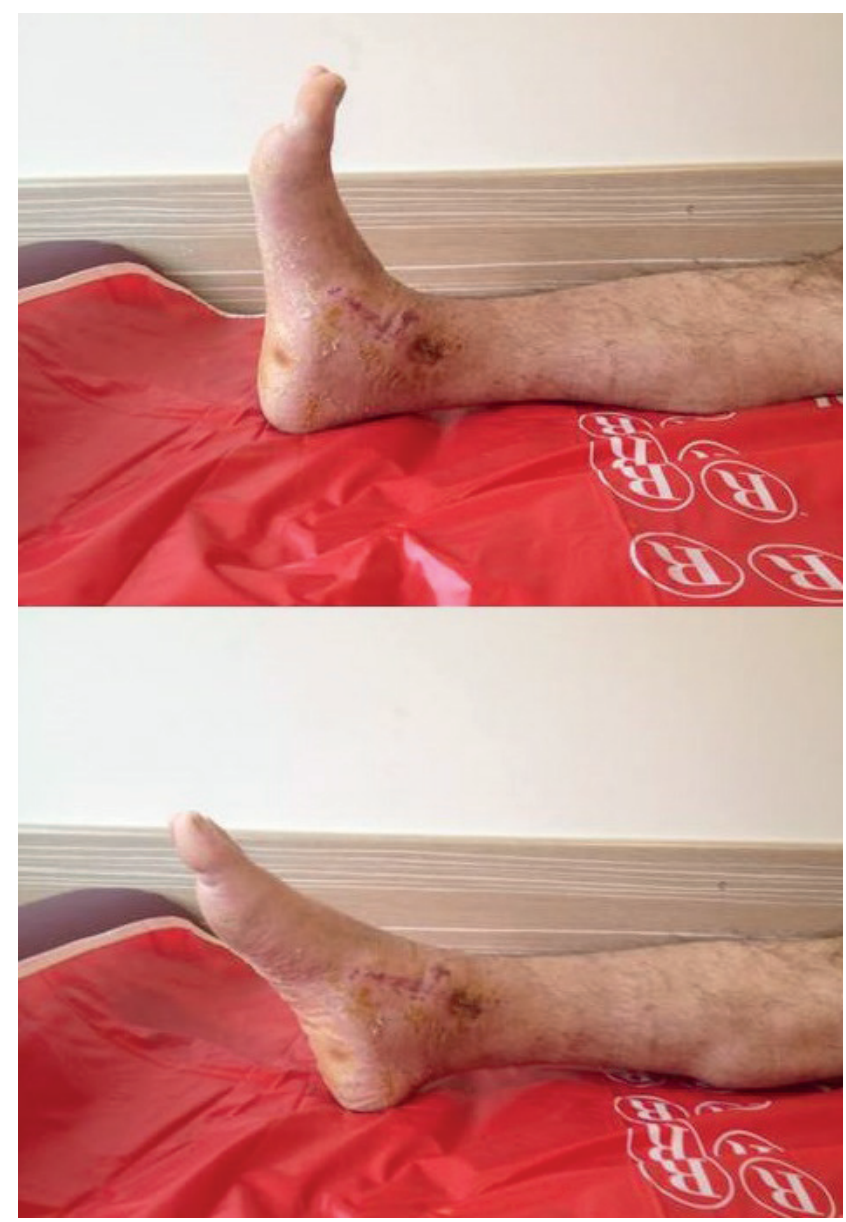

Figure 4. The patient had full movement of the ankle three months after surgery 
of a tibialis anterior rupture, but the diagnosis of a ruptured tendon accompanied by a medial malleolus fracture may be overlooked during the physical examination because of pain, swelling, and the limited movement due to the fracture. Direct roentgenograms may demonstrate avulsion fractures at the insertion site. The diagnosis can be confirmed by ultrasound and magnetic resonance imaging (MRI) $(9,16)$. Early diagnosis of the tendon rupture is very important because early repair of the tendon results in a better outcome, whereas delayed surgery often requires grafting and has a lower success rate (17). In this rare injury, surgeons may be suspicious on tendon tension during surgery, and physical examination findings such as edema, swelling and ecchymosis in tendon insertion could be doubted.

Screw fixation and tension band wiring techniques are the most popular fixation methods for medial malleolus fractures (18). Screw fixation could be made by cannulated screws or malleolar screws. The surgeon selects the method depending on the type of the fracture, the size of the fragment, and bone quality, etc. (19). All these methods have successful rates. These fixation techniques are quite stable. In this case, we preferred open reduction for displaced fragment reduction and screw for stable fixation.

Of all the cases reported in the literature, tendon tears accompanying a medial malleolus fracture were diagnosed intraoperatively, and treated with the fixation of the medial malleolus and primary suture of the tendon (6). All the malleolar fractures previously presented were accompanied by posterior tibial tendon ruptures. Din reported a case of anterior tibial tendon injury associated with a closed midshaft tibial fracture (20). However, there have been no reports of medial malleolus fractures accompanied by anterior tibial tendon tears in the literature. In this case, the anterior tibial tendon tear was detected during surgery for the medial malleolus fracture. Depending on the shape of the fracture, this injury may occur due to trauma and direction of the forces applied to the foot. The tendon ruptured from its insertion site, unlike those presented in the literature, and was attached to the navicular bone using two anchor sutures after the stabilization of the medial malleolus fracture. No complications occurred and the patient had full movement of the ankle three months after surgery.

Although it is a very rare occurrence, anterior or posterior tibial tendon tears may accompany medial malleolus fractures. Lack of an early diagnosis can result in major complications. Thus, palpation of the tendons and checking for local tenderness are very important during the physical examination. Patients should be evaluated with ultrasound and MRI in addition to radiographs if required.

\section{Authorship Contributions}

Surgical and Medical Practices: S.H.B., E.S. Concept: S.H.B., E.S., M.Ç. Design: S.H.B., H.N.Ö. Data Collection or Processing: E.S., M.Ç. Analysis or Interpretation: S.H.B., H.N.Ö., A.B. Literature Search: S.H.B., A.B. Writing: S.H.B., H.N.Ö., A.B.

Conflict of Interest: No conflict of interest was declared by the authors.

Financial Disclosure: The authors declared that this study received no financial support.

\section{References}

1. Greenfield DM, Eastell R. Risk factors for ankle fracture. Osteoporos Int 2001;12:97-103.

2. Marsh JL, Saltzman CL. Ankle fractures. In: Bucholz RW and Heckman JD editors. Rockwood and Green's Fractures in Adults. Philadelphia: Lippincott Williams and Wilkins; 2002:2001.

3. Daly PJ, Fitzgerald RH Jr, Melton LJ, Ilstrup DM. Epidemiology of ankle fractures in Rochester, Minnesota. Acta Orthop Scand 1987;58:539-44.

4. Court-Brown CM, McBirnie J, Wilson G. Adult ankle fracturesan increasing problem? Acta Orthop Scand 1998;69:43-7.

5. Al Khudairy A, Zafar MM, Padinjarathala BA. The unexpected with ankle fracture: traumatic tibialis posterior tendon dislocation: a case report and literature review. Foot Ankle Spec 2013;6:482-9.

6. West MA, Sangani C, Toh E. Tibialis posterior tendon rupture associated with a closed medial malleolar fracture: a case report and review of the literature. J Foot Ankle Surg 2010;49:569-72.

7. Standring S. Gray's Anatomy-The Anatomical Basis of Clinical Practice. 40th ed. New York: Churchill Livingstone Elsevier; 2008:1417-8.

8. Constantinou M, Wilson A. Traumatic tear of tibialis anterior tendon during a Gaelic football game: a case report. $\mathrm{Br} J$ Sports Med 2004;30-8.

9. Rodrigues ME, Periera A, Alpoim B, Geada JM. Traumatic rupture of the tibialis anterior tendon: a case report. Rev Bras Ortop 2013;48:278-81.

10. Trout BM, Hosey G, Wertheimer SJ. Rupture of the tibialis anterior tendon. J Foot Ankle Surg 2000;39:54-8.

11. Gwynne-Jones D, Garneti N, Wyatt M. Closed tibialis anterior tendon rupture: a case series. Foot Ankle Int 2009;30:75862.

12. Jerome JT, Varghese M, Sankaran B, Thomas $S$, Thirumagal, SK. Tibialis anterior tendon rupture in gout - case report and literature review. Foot Ankle Surg 2008;14:166-9.

13. Aydingöz $U$, Aydingöz $O$. Spontaneous rupture of the tibialis anterior tendon in a patient with psoriasis. Clin Imaging 2002;26:209-11. 
14. Miller RR, Mahan KT. Closed rupture of the anterior tibial tendon: a case report. J Am Podiatry Med Assoc 1998;88:3949.

15. Otte $\mathrm{S}$, Klinger HM, Lorenz F, Haerer T. Operative treatment in case of a closed rupture of the anterior tibial tendon. Arch Orthop Trauma Surg 2002;122:188-90.

16. Khoury NJ, el-Khoury GY, Saltzman CL, Brandser EA. Rupture of the anterior tibial tendon: diagnosis by MR imaging. AJR Am J Roentgenol 1996;167:351-4.

17. Sammarco VJ, Sammarco GJ, Henning C, Chaim S. Surgical repair of acute and chronic tibialis anterior ruptures. J Bone Joint Surg Am 2009;91:325-32.
18. Khurana S, Karia R, Egol KA. Operative treathment of nonunion following distal fibula and medial malleolar ankle fractures. Foot Ankle Int 2013;34:365-71.

19. John R, Dhillon MS, Khurana S, Aggarwal S, Kumar P. Tension band wiring is as effective as a comprehension screw in a neglected, medial malleolus non-union: a case based discussion \& literature review. Journal of Orthopaedic Case Reports 2017;7:72-5.

20. Din R, Therkilsden L. Rupture of tibialis anterior associated with a closed midshaft tibial fracture. J Accid Emerg Med 1999;16:459. 